\title{
Legilinguistic Features of a Semantic Field: COVID-19 in Written News/Media in Hebrew and Arabic
}

\author{
Judith Rosenhouse ${ }^{1}$
}

Accepted: 20 July 2021 / Published online: 30 October 2021

(c) Springer Nature B.V. 2021

\begin{abstract}
This paper examines and compares some legilinguistic features in news/media reports in Hebrew, and in Arabic in Israel and Egypt during the COVID-19 pandemic in 2020 and the beginning of 2021. The goal was to find frequent and innovated expressions in the communication media during the COVID-19 period. The research question was, since there are linguistic differences between these language-varieties: would differences be found also on the legilinguistic level? Hebrew and Arabic were studied because of their different status. In Israel, Hebrew is the dominant official language, while Arabic is a minority language. In Egypt, Arabic is the official and dominant language. The material was collected from two news/media channels in each of Modern Hebrew and Arabic in Israel, and two from Egypt. Selected news texts were analyzed and examples of their lexical and syntactic elements are presented. The texts revealed similar methods for controlling the pandemic, and some linguistic (lexical and syntactic) differences. The comparison with legilinguistic literature suggests that the findings of these Hebrew and Arabic texts' features during the pandemic differ from features discussed in other studies.
\end{abstract}

Keywords COVID-19 pandemic $\cdot$ Linguistic expressions during the COVID19 pandemic $\cdot$ Legilinguistic expressions in Hebrew (Israel) $\cdot$ Legilinguistic expressions in Arabic (Israel) · Legilinguistic expressions in Arabic (Egypt)

\section{Introduction}

This paper examines and compares some legilinguistic features in news/media reports in Hebrew and Arabic in Israel and in Egypt during the COVID-19 pandemic in 2020 and ends in April 2021, when somewhat more than half the Israeli population was inoculated.

Judith Rosenhouse

judith@swantech.co.il

1 Technion - I.I.T., 9 Kidron St., 3446310 Haifa, Israel 
The language situation in Israel is more complex than in Egypt [26]. Native Egyptian speakers of Arabic normally use their colloquial Egyptian Arabic dialects and some elements of Modern Standard Arabic (MSA), the contemporary variety of written (literary) Arabic. (MSA is used mainly for official, religious, literary, and journalistic communication [11,20], but it is not the mother tongue.)

In Israel, however, native speakers of Arabic use their local colloquial Arabic dialects mainly in their communities, and Hebrew-with Hebrew speakers for much of the daily communication on official and cultural issues. Arab students in Israel study MSA from the first grade and Hebrew from the third grade until the end of high school, and they use Hebrew also in higher education institutes. In any case, MSA is not the mother tongue of native speakers of Arabic and lexical and structural differences exist between MSA and the many colloquial dialects. Still, MSA elements occur in the speech of native speakers of Arabic following their educational achievements. On the other hand, Jewish Hebrew speakers study colloquial Arabic and MSA for few years along school years. (Modern Hebrew has been influenced also by colloquial Arabic ([15, 21, 51]), but less than Arab speakers in Israel have been influenced by Hebrew).

In June 2020, the population in Israel consisted of a Jewish majority, about 20\% Arabs and about 5\% others [35]. Not all this population is comprised of native speakers of Hebrew, though it is the official and dominant language in the country. Local native speakers of Arabic dialects include Muslims, Christians, Druze, Circassians, and a small proportion of Jews.

Due to this situation, native speakers of Arabic in Israel as well as elsewhere mix or code-switch their local colloquial mother tongue with MSA, usually revealed in lexical items and some grammatical elements. This dual language situation of Arabic was named 'diglossia' $([5,11])$. Arab speakers' language choice, thus, often depends on speakers' and interlocutors '/ readers' language skills and education ([9, $15,19,20])$.

Since native speakers of Arabic in Israel are exposed to Hebrew on the street, the media, and official avenues, Hebrew affects their language use (cf. $[15,18])$. Thus, in Israel, many Arabs (if not most of them) mix their local dialects or code-switch it with spoken Hebrew, to the extent that some call their language' aravrit (<'Aravit +'Ivrit 'Arabic + Hebrew', in Hebrew) [25] or Arabrew (Arabic + Hebrew, in English). ${ }^{1}$ Many works describe and discuss this profuse code switching with Hebrew in spontaneous Arabic speech (e.g., [6, 7, 15, 25]).

Towards the beginning of 2020, first news about an endemic virus started to spread in Israel. The purpose of this paper was, therefore, to examine linguistic effects of COVID-19 in three language varieties: Modern Hebrew, MSA in Israel, and MSA in Egypt during the pandemic. Due to these three examined language

\footnotetext{
${ }^{1}$ The transcription system for both written Hebrew and Arabic is the one used in e.g., Brill publications, though in speech they are only partly distinguished. See, e.g., Hebrew h-x, x-k, t-ț, v-b, -'-h, c stands for the affricate ts, and $\breve{g}$, $\check{z}$ reflect borrowed (foreign) speech sounds. Accented vowels mark the stressed syllable in the Hebrew words. For Arabic the symbols š, ș, d, t, t, ğ, h, x, ġ, q occur where needed. Long Arabic vowels are marked thus: $\overline{1}, \bar{u}, \bar{a}, \bar{e}, \bar{o}$. All Hebrew and Arabic words are written in Bold font.
} 
varieties' linguistic features, as described in linguistic literature, the basic hypothesis was that some differences between expressions related to COVID-19 in Israeli Hebrew, MSA in Israel and MSA in Egypt may be found, and that the lexical field could reflect the linguistic differences better than other language structures. ${ }^{2}$ No existing theory was therefore initially adopted, but semiotic and legilinguistic aspects were constantly taken in consideration.

The structure of the paper includes, first, the method of work, and the sources of the material are presented below. These are followed by a short description of the situation in 2020-2021 in Israel, and by relevant examples from the collected material of the three language varieties. The discussion of the study leads to the conclusions.

\section{Method and Material}

Material collecting for this study began in 2020 and ended in April 2021, when somewhat more than half the Israeli population was inoculated. The hypothesis was that the lexical field would reveal the linguistic differences more clearly than other language structures, since law-related writing has its specific features in many languages, including Hebrew and Arabic (cf. e.g., [3, 13, 14, 22, 32]). This paper analyzes and discusses, therefore, law-related expressions in these languages. Though the news texts do not normally use a high, formal register, as found in legal documents, the need to discuss topics related to laws and authority of newly ordered behavior rules transmits to the readers hints of that register.

The basis for this work is material found in two Israeli newspapers/news sites in Modern Hebrew, which were accessed online during 2020-2021. The texts referred to COVID-19 and included some of the official instructions and regulations of that period. This material was compared with MSA as used in two Arabic online newspapers/media sites in Israel and in two Egyptian MSA ones. Altogether, 44 texts in Hebrew, 57 texts in MSA from Israel and 62 Egyptian MSA texts were used. The sum of their words differed, too: several texts were longer than one page, but most of them had between 5-15 lines. Lexical items i.e., expressions of one word or more than a word that were frequently used during the pandemic and were partly related to various legal issues, were examined and examples are presented in this paper.

For Hebrew, the news/media sites were Yisra'el Ha-Yom ('Israel Today') [41], a daily newspaper that supports the Likud political party in Israel, and appears both in print and online. The other source in Hebrew was a major competitor, Ynet, [42], the media version of Yedi'ot 'Aḥaronot ('Recent News') [42], which is a privatelyowned paper-print newspaper.

\footnotetext{
2 In this paper, COVID-19 and Corona are used interchangeably, because the popular name of this pandemic in both Israel and Egypt is Corona, while the name COVID-19 is used in these countries in rather formal contexts. In the Hebrew and Arabic examples, the written name is as in the original text.
} 
Similar MSA material was studied through Panet [39], a privately owned Israeli online news net, also printed as the newspaper Panorama [40]. ${ }^{3}$ This medium is very popular in the local Arabic-speaking population. The other MSA news/media site from Israel was Kull al-'Arab ('All the Arabs') [37, 38], another privately owned newspaper, which also appears online, and focuses on local news of the Arab population in Israel, in addition to general world news.

For MSA in Egypt, 'Al-'Ahrām ('The Pyramids') [33], the official newspaper of the government in Egypt, and its portal Bawwābat 'Al-'Ahrām ('The Al-Ahram portal') [33] were studied. The other Egyptian MSA source was 'Al-Yawm 'Al-Sābi' 'the seventh day', [34] also called 'Axbār 'Al-Yawm 'Al-Sābi' [34], 'The Seventh Day News'. The latter had (allegedly) the highest net-viewers' rate in Egypt nowadays.

Since most of the texts in any newspaper or internet site are not specifically law-related, the analysis is linguistic and semantic (rather than semiotic), and the terminology here is rather linguistic than legalistic. Thus, the term "lexical item" is used here for an examined single word, a phrase with more than one word, or a specific scientific or legal term in Hebrew and Arabic. The analysis reveals also grammatical and semantic differences between the three examined language groups (as expected). All these elements are discussed and lead to the conclusions.

Obviously, the material in these sources could not be (lexically) identical, for the news/media were not literal translations of each other, although the texts dealt with similar COVID-19 topics. As the relevant events and data concerning COVID-19 affected the examined news in a similar manner, the topics, the contents and vocabulary were often similar, and enabled comparison. In addition, a text in Hebrew and its MSA (in Israel) translation is discussed below. Still, since the texts were not literally identical, a statistical analysis of identical lexemes or notions could not be performed.

\section{COVID-19 in Israel, 2020-2021}

In Israel, first news about a new infectious disease from China started to spread in December 2019. In gradually larger numbers of countries, patients were contracting this disease. Israel was like other countries in this sense. People were listening to the news and to the Prime Minister's (PM's) regular announcements about the state of the disease, for which the word magefá, 'pandemic' began to circulate. Efforts to understand how to treat the patients and new regulations concerning people's behavior outside the hospitals were hourly broadcast on all the media.

By March 14th, the publicly advertised regulations in Israel developed to a total lockdown. Seventy per cent of the work places, all public transportation, including flights, and public cultural activities involving crowds, were stopped. Leaving home was banned, except for acquiring provisions and medications, and

\footnotetext{
${ }^{3}$ Panet/Panrama are written in Arabic with $\mathbf{b}$ instead of $\mathbf{p}$, since Arabic orthography (and phonology) lacks p.
} 
only when wearing facemasks and gloves (except for special medical cases). This state lasted for more than a week, with some changes in the regulations following public inability to run their lives with them. Public complaints were growing, as more people were falling ill, and the death toll began to rise, in particular among the elderly.

Medical details about the virus were gradually accumulating, while hospitals were trying various treatments to cure the patients. Seclusion and distance keeping were obligatory when meeting with anyone not of one's nuclear family. Research aiming at producing vaccines or serums to cure the patients or immunize others was going on. By summer 2020, many companies (including a few Israeli ones) were experimenting their new medications with human volunteers. Yet, mass inoculation was still just a distant dream.

In Israel, since May, the limitations were gradually eased off. During the spring months (March to June) many different religious holidays and weddings took place in all the communities. These events involved crowding and violation of other regulations. In response, the authorities locked down synagogues and mosques, an unheard-of measure until that time. Still, the Arab minority and the ultra-orthodox Jewish communities in Israel were suffering from COVID-19 in growing numbers, more than other proportions of the Israeli (Jewish) population.

This led to re-introduced limitations, after the temporary relapse. Three major regulations remained constant, however: wearing facial masks in public areas, keeping $2 \mathrm{~m}$. distance between individuals, and prohibited crowding in public places (outdoors and indoors).

By August, various companies worldwide announced that they were trying their inoculation products on human volunteers. At the end of August, the "traffic light system" was declared (but hardly applied). This system was thus named due to the red, orange, yellow and green colors, marking four severity degrees of the pandemic in the different towns and villages. But, on September 25th, the second lockdown in Israel was declared due to the growing severity of the pandemic wave.

This second lockdown and its tighter regulations began on September 18th, just before the eve of the Jewish New Year. The regulations were heeded only by a proportion of the population. Although penalties were set for violation of regulations, the police hardly enforced them, allegedly due to political pressures. However, since October, certain regulations were gradually eased off.

By this time, after almost a year, the pandemic was not 'news' anymore. Its special vocabulary was used as a matter of course. However, all the time, the media continued reporting the state of the pandemic and the efforts to control it. They also reflected the people's (and media's) responses to the management of public health problems.

The pandemic and lockdowns also caused unemployment and "unpaid vacation" rise to the unprecedented rate of about $20 \%$ (or a million people) in Israel. Somewhat late, in April 2020, the government offered some financial help, but it did not solve all the problems. The financial difficulties, the government's hesitant policy regarding the pandemic, and internal political difficulties, pushed hundreds of thousands of veterans and younger people to organize demonstrations, which continued all year long all over the country, including the capital, Jerusalem. On 
December 23, 2020 the government collapsed. This event was necessarily followed by elections on March 23, 2021. (A new government was formed only in June 2021.) The general pressure due to the pandemic and the following regulations naturally affected these events.

This second wave of COVID-19 was already so bad, that in December, Israel reached the head of the list of global "red countries" with a third of its population infected and a relatively high death rate. The pandemic continued with a third lockdown from 27.12.2020, which lasted with partial and gradual mitigation of the limitations until May 2021, while death cases due to the pandemic reduced to zero on April 23, for the first time since 2020. (Afterwards, it started growing again.)

In December 2020, news began to spread about the success of the medical efforts to stop, cure or prevent the spread of the pandemic. A "good news" report of this kind [55] (Yisra'el Ha-Yom, 23.9.2020) announced a successful treatment of 11 out of 12 COVID-19 virus patients also by an Israeli institute. But the first antiCOVID-19 vaccines arrived in Israel in about mid-December 2020. Within about 3 weeks (December 2020-January 2021) about 1.5 million high-risk citizens ( $>60$ years old) were inoculated at least with the first of two injections. (The second injection was due 3 weeks after the first one.) Gradually, younger people were also inoculated. By April 2021, about 5.5 million people had got at least the first injection.

In sum: by mid-April 2021, the pandemic caused in Israel three lockdowns, more than 6300 death cases, about 5.5 million inoculated people, less than $1 \%$ newly confirmed sick people, and about 250 severely ill patients in hospitals. The financial state of Israel deteriorated, not all the unemployed people regained their jobs, since many workplaces had closed down. The pandemic has not ended, but life is going on. The situation in Egypt was and is different, because of its different conditions. However, there too, the inoculation is proceeding.

\section{Analysis of Lexical Items from the COVID-19 Vocabulary in Israeli Hebrew}

The relevant law-related vocabulary that was used during this period in the above Hebrew newspapers is classified here into three groups:

(1) Modern Hebrew words frequently used during the COVID-19 period (e.g., hanḥayót 'instructions')

(2) Borrowed or translated words, mainly from English during this period (e.g., qápsula, < 'capsule', i.e., 'bubble' (UK), used for 'small groups of schoolstudents, instead of full-scales classes in a classroom').

(3) Newly coined Hebrew words or such with expanded meanings in this period (e.g., tixlúl "integration, inclusion").

More details follow. 


\section{Lexical Items of the COVID-19 Vocabulary}

It seems that three words can serve as major keywords of the COVID-19 period in Israel, and probably elsewhere: séger 'lockdown', bidúd 'isolation, quarantine', hisuním 'inoculations' ([8]). Over 2020, these words became gradually frequent, in private and public discussions and reports. Table 1 lists twenty expressions as examples of the vocabulary that has become very frequent during this period in Hebrew newspapers/media.

The lexical items in Table 1 are part of the Hebrew vocabulary, and do not necessarily belong to the judicial context. However, they can have threatening connotations and implications of new and aggressive processes or events that are taking place, or will take place, due to new regulations by the authorities. Their judicial underlying contexts may disrupt normal routine and life. Cf.: (1) 'isolation', (4) 'disorderly conduct, disturbance', (6) 'recommendations', (7) 'binding instructions,' (11) 'gathering/crowding prohibition,' (14) 'malfunction (of the old people's homes)', (15) 'penalties for violation of regulations,' (17) 'complete lockdown,' (18) 'regulations' and (19) 'obligation (of) wearing masks.'

Because of the belligerent atmosphere of quarrels, wars and everything that they involve, the threats are more explicit in the following expressions: (5) 'Civil defense/ civilians' protection.' (8) 'Announcements to the nation.' (13) 'Motels ( hotels) used for the quarantined sick.' (16) 'Home front command (a unit of the Israeli Defense Force that helped the police forces in various civilian duties during the pandemic).'

Listeners may expect a crucial matter, pertaining to most of the population, if a PM delivers speeches and gives 'announcements to the nation' (8) about new 'instructions' (3), 'recommendations' (6), 'inhibition of events with audience' (10), 'computer-aided learning (CAL)' (12), or 'regulations' (18). Moreover, since the PM delivers such speeches and announcements, his speeches bear an official and ominous character: normal law and order is soon to change the people's life in some serious manner(s).

Even recurring expressions such as (2) 'public health', (9) 'flattening the curve' (of the sick rate graph) and (20) 'verified sick (persons)' imply many health problems in the population and official surveillance of the situation. All these expressions are associated with changed laws and new dangers. Such expressions imply also that something is wrong with the current system, and this situation may (or will) affect the whole country. Although on the face of it, such lexical items are part of the "normal" daily vocabulary, they also relate to, and reflect the law and order system in society.

The description in this part suggests that even simple expressions such as in news/media reports, can have semiotic load and meaning for the reading/listening audience. 


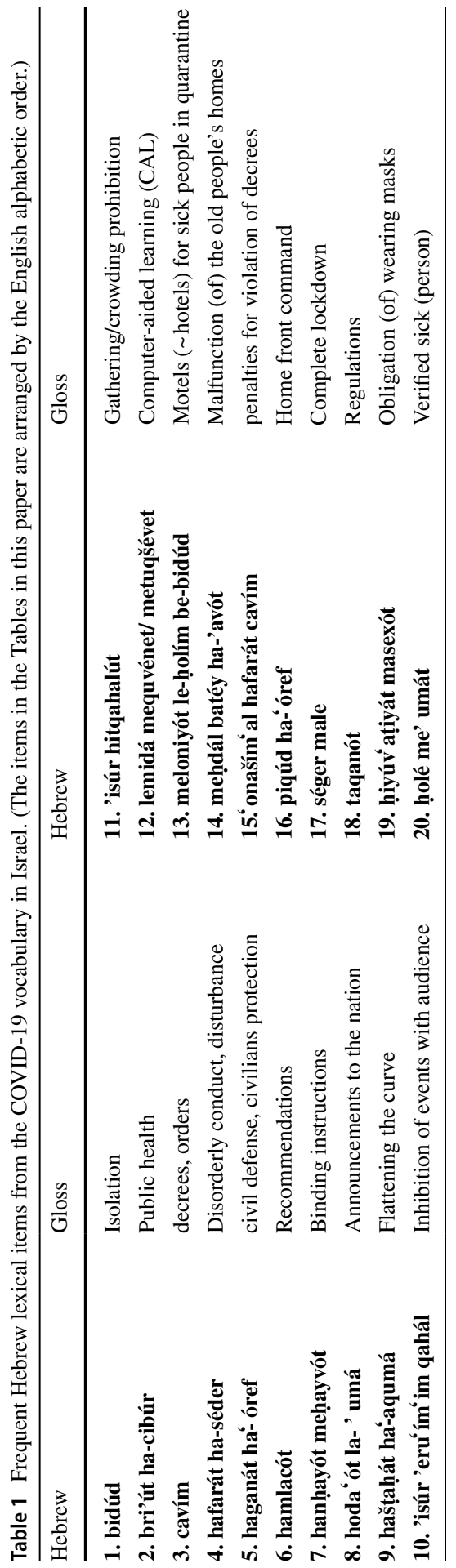




\section{Borrowed or Translated Words in Israeli Hebrew Related to the COVID-19 Pandemic}

The following examples (some of which appear also in Table 1 above) include lexical expressions that are not of Hebrew origin. These terms relate to the current pandemic, and appear on the news/media in the studied texts. (Explanation of several such medical terms in the daily use see in the Hebrew Academy site [16, 36].)

diqtátor - 'Nickname' for the Prime Minister by demonstrators protesting about his policy in particular during the COVID-19 crisis.

hakirá epidemiyológit - '(an) epidemiological investigation,' i.e., a medical study type during the pandemic.

mivhán serológiya - 'a serological test.'

qápsula 'capsule', borrowed into Hebrew in the twentieth century to refer to medical pills. During the current pandemic, this term referred to the allowed spaces for small groups of humans who stay in, e.g., a small learning space instead of classrooms ([49]) (cf. 'bubble' in the UK).

pandémia - 'pandemic', a global epidemic; now applied for COVID-19 in Israel and elsewhere (not used previously in Hebrew). During 2020 this foreign word was ousted by the Hebrew word magefá 'pandemic' which was previously of a higher discourse register.

re'agént - 'reagent, a chemical element that creates a chemical reaction'; in Israel this term was often used in the context of COVID-19 in the beginning of 2020. In 2021, it is scarcely mentioned.

téyq-awéy (take-away, as written in Hebrew) - an expression referring to food prepared, bought and taken home instead of being consumed at the restaurant. This English term was used in Israel before the pandemic, but it has become very popular due to the COVID-19 lockdowns.

haḥragá - a judicial expression meaning 'exception, exclusion of some element from the general rules' (here: exclusion from a public body).

mediná 'adumá - 'a red state', the color that marks that a State has severe COVID-19 spread rate. This expression originates in traffic lights, where a red light signals for drivers and pedestrians to halt. It has been borrowed to the 'traffic light system' during the current pandemic.

meqadém ha-hadbaqá - ' $R$,' the statistical coefficient, used currently for the COVID-19 pandemic infection spread rate.

rihúq ḥevratí - 'social distancing' - this is a sociological notion, but now also relates to the requirement to avoid crowding (in order to prevent COVID-19 virus spread).

taḥlu'á - 'public disease rate,' (morbidity) found already in the Hebrew dictionary of medical terminology [16] (1939), but rarely used in general communication before the pandemic.

The above nouns and nominal phrases reflect foreign technical terms of the medical parlance as used in Hebrew news/media reports about the pandemic. These terms (and others) are translated from foreign languages into Modern Hebrew. (Translations into Hebrew were in the twentieth century mainly from German, 
Russian, Polish, English and Yiddish.) Some of the examples above have newly expanded meaning due to their use under the new circumstances. They literally imply (or denote) the need for expressions adapted to the new medical circumstances of the pandemic, and thus their semiotic application.

\section{COVID-19 in Legal Documents in Hebrew}

Israeli official authorities, offices and bodies publish their new regulations and decisions concerning the COVID-19 pandemic in various public media on the internet. The Ministry of Health, for example, issues its reports on the site gov.il/ health in Hebrew, English, Arabic and Russian. Other ministries, e.g., Finance Ministry, Internal Security Ministry, Education Ministry, and Ministry of Justice also deal with their respective aspects of the citizens' life under the pandemic. The Israeli Police is responsible (among its other tasks) for the population's obeying the new regulations. A Ministry of Justice document [12] consists of instructions and behavior rules in courts and labor courts during the COVID-19 period (updated 25.11.2020). Court sessions were postponed during 2020, and all lawyers, judges and other people who work in this field or receive its services got relevant information at least via these usual formal ways. Such documents are written in the formal, high-registered style of legal documents ('legalese'), which does not use emotional expressions or friendly (informal) language. Issues of Hebrew legal style and criticism of other (complex) linguistic features in legal documents are discussed in e.g.,[3, 4], and in publications of the Israeli Bar Lawyers (see, e.g., [23, 24]), aiming at improving grammatically complicated style by more straightforward structures. The fact that a case is tried during this difficult year is explicitly mentioned in official documents only when it is necessary to refer to limitations or give instructions concerning the current circumstances of the pandemic.

An example of such formal-legal documents is a police document [49] (updated on 18.8.2020), which lists the instructions for civilians' behavior in public spaces and penalties for disobedience and violation of the new instructions. Most of the document, and its lexical and syntactic structures, relate to those issues. This document appeared first in Hebrew on 17.8.2020. On the following day, as usual, an accurate translation into Arabic appeared [50]. Russian or Amharic translations of this document (which are languages of the other large minorities in Israel) could be found in the police site only later (from 30.8.2020). Table 2 presents 20 relevant Hebrew expressions found in this document.

The examples in Table 2 show that the authorities deal with the situation by a system of "do" and "do not do" instructions, i.e., positive and negative imperative statements. In other words, the document states what the public can/cannot or need / need not do in public spaces. The document also threats the public with penalties in cases of violated instructions.

In this document, these instructions are expressed in five syntactic structures demonstrated in the examples below: a positive/negative imperative verb form and four impersonal structures with an infinitive (e.g., "(not) to participate in...”) instead 


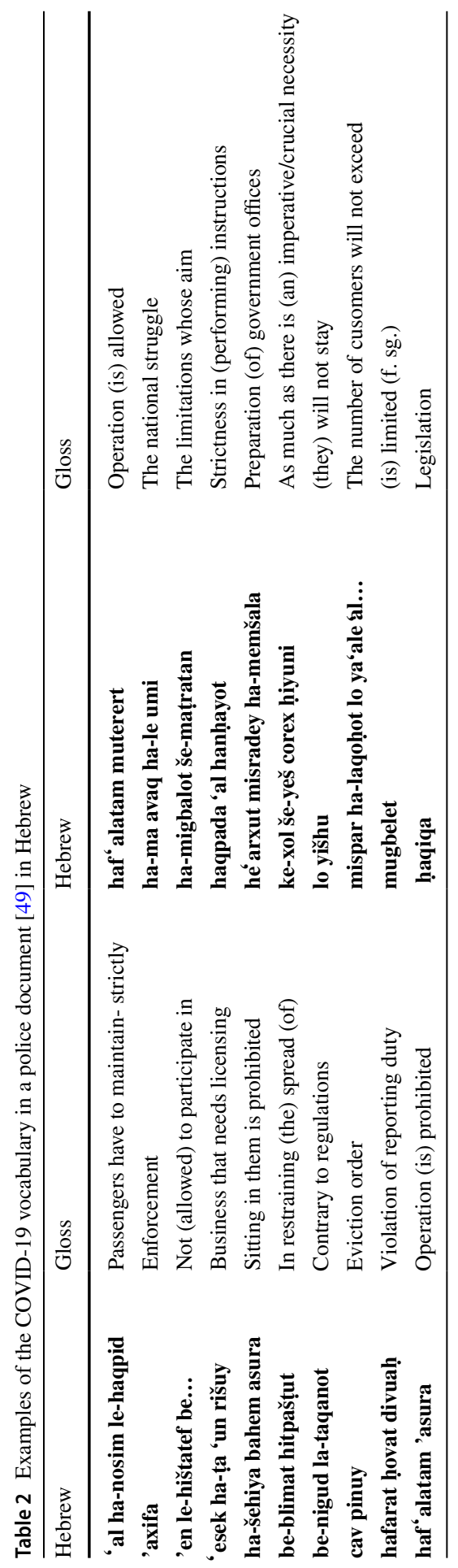


of a conjugated personal agent (e.g., "(they) will not participate in...”). See the following examples:

1. lo yišhú 'will not reside/stay (3 m.pl.)', This example 1 is a verbal sentence, where the negative particle (lo 'no, not') is followed by the negated verb yišhú 'they-will-stay' in the future tense, plural masculine 3rd person (the future tense is marked by the prefix yi- and the person is marked by the final suffix -ú $)$. The pattern [negative particle (e.g., lo) + plural future verb] implies a general negation of the action specified by the verb (the predicate).

2. 'isúr hitqahalút 'Prohibition (of) crowding.' This example shows a construct state pattern, where the first word isúr ('prohibition') is followed by the noun/verbal noun 'crowding'. The construct state is a very frequent structure in Hebrew.

3. 'én le-hištatéf be... 'not to-participate in'. Example 3 is another non-verbal pattern, where the infinitive le-hištatéf is used. This infinitive is introduced by the preposition le- 'to'. The infinitive verb form then governs be- 'in,' another preposition, which governs the indirect object (not cited here). The example begins with the negative particle 'en (lit. 'is not') which negates the infinitive 'to participate' and syntactically serves as predicate where le-hištatef be... is the subject phrase.

4. 'al ha-nos 'ím le-haqpíd 'passengers have to keep strictly... ('lit.: On the passengers to-keep-strictly'). This example has an infinitive verb form in a positive structure. The passengers' responsibility here is expressed by the preposition 'al 'on' which governs the definite noun ha-nos' ím 'the passengers' and the following infinitive verb form, le-haqpíd, which provides the notion of the needed action.

5. (ha-)šehiyá bahém 'asurá '(the) stay in them is prohibited.' Example 5 uses the passive participle 'prohibited' 'asurá in the pattern [SUBJECT (noun) + prepositional phrase 'in them' (is) + passive-participle]. This structure is the opposite of ex. 2: in Ex. 2 the prohibition ('isúr) is the first (governed) component of the construct structure, and in ex. 5 it is the last component. (Morphologically it is a passive participle and syntactically it is a predicate).

Other structures in this document reflect the semantic level rather than syntax. See:

6. hafarát ḥovát divúạ̣ 'Violation (of) duty (of) reporting.

7. haqpadá 'al hanḥayót 'Strictness in (keeping/performing) instructions'.

8. cav pinúy 'order (of) eviction'.

9. ke-xól še-yéš córex hịuuní 'As much as (there) is an imperative/crucial need'.

10. 'ések ha-ța' ún rišúy 'a business which needs (lit. 'is subjected to') licensing'.

The nouns in examples 6-9 use the semantic field of 'fulfilling orders' by different lexical items and imply the need to comply with the official orders. Example 10 involves a passive participle form, tạ ún (lit.: loaded; i.e., requires, needs), which governs an accusative (the verbal noun rišúy), in a noun form, i.e., "licensing". In these examples, morphology and syntax shape the semiotic aspects of the utterances.

Table 3 presents some expressions reflecting additional legilinguistic issues found in the news/media texts. They report the various judicial aspects in the considerations about what measures to take due to the pandemic: tightening the 
instructions, where and when to tighten them, how they will affect the population (workers, soldiers, etc.), which group will do it, etc.

Court rulings also appear in some of the texts, like other legilinguistic topic. In 2020, many sessions were postponed during lockdowns because of the pandemic. Table 4 below presents examples from the High Court of Justice's ruling [43] about stopping the Israeli General Security Services (GSS) activity in locating forbidden contacts between COVID-19 infected people and others, as cited in Yisra'el el Ha-Yom. These examples demonstrate the issue, the arguments and the ruling.

The legalese style in these quotations (Table 4) is expressed in the profuse use of the construct state (in its two patterns: [noun+ noun], long constructs [noun + noun + noun (+ noun)] and [noun + suffixed pronoun + šel ('of') + noun]. Another feature is the use of many adjectives - also nominal structures. These nominal elements lengthen the sentences as part of the complex nature of legalese, on account of conjugated verb forms. Note, however, that in Hebrew, such elements are common to many formal, theoretical and academic discourse types, and not only to legalese, i.e., legal documents.

\section{COVID-19 (Corona) Expressions in Arabic}

\subsection{Arabic News/Media in Israel}

Arabic and Hebrew vocabulary does not (cannot) have exactly the same structures and patterns, although they are two sister-languages of the Semitic languages group. It should also be noted that Arabic is a language with diglossia, i.e., it has sharp differences between its written, "higher" register (MSA) and the "lower" colloquial dialects. The effects of a foreign language like Hebrew on Arabic vary also between these two registers (e.g., [2, 27, 28, 45, 51]). The examined news/media press kinds are among the most popular ones in Arabic in Israel, presenting the news of the Arab society in their towns and villages, as well as general world and country news. These texts are written in MSA. The relevant Arabic expressions found in the texts can be grouped into four lexical discourse types, also found in the Hebrew news/ media texts, namely, judicial; psychological; medical/scientific; and administrative.

Table 5 displays examples from the official Arabic translation [50] of the mentioned Hebrew police document [49]. This document appeared in the Panet/ Panorama site already on 5.6.2020. (Somewhat later, it was found also in kull al'Arab, accessed on 27.7.2020). The document details the instructions for civilians' behavior during the COVID-19 period in various business places and public places. In both the Hebrew and the Arabic versions, there are many 'fighting' metaphors, which reflect the efforts exerted against the pandemic.

As in Table 2, the translated text uses the passive participle mamnū' and the passive imperfect tense yumnáu, i.e., 'prohibited' and the (impersonal) active imperfect verb form yağibu '(is) obligatory.' Other examples show negated passive verbs lā tūğadu ('is not found') or nominal structures (e.g., 'adam 'lack (of)' (for refuting the regulations. Some verbs appear in the past tense, implying a 'fait accompli' (e.g., a commercial business (whose) activity was already prohibited). 


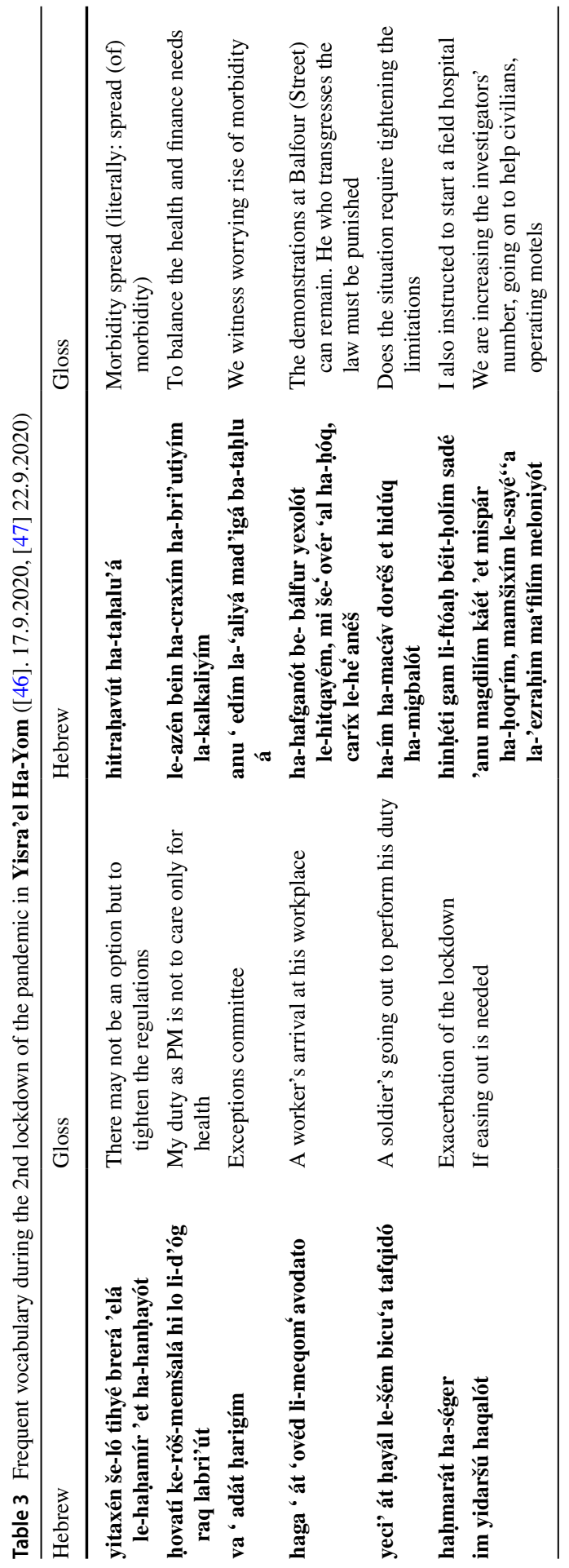


Table 4 Frequent vocabulary from Court ruling in Israel, Yisra'el Ha-Yom, ([43] 1.3.2021)

\begin{tabular}{|c|c|}
\hline Hebrew & Gloss \\
\hline ikunéy šabák & GSS positioning \\
\hline $\begin{array}{l}\text { hitbaqéš béit-ha-mišpáṭ le-horót' al baṭlutó šel } \\
\text { ḥóq hasmaxát ha-šabák }\end{array}$ & $\begin{array}{l}\text { The court was requested to order the repeal of the } \\
\text { "GSS accreditation Law" }\end{array}$ \\
\hline ...yufsáq ha-šimuš ha-goréf ba-šabák & $\begin{array}{l}\text { The all-inclusive use of the GSS... should be } \\
\text { stopped (literally: ... will be stopped, the all- } \\
\text { inclusive use of the GSS... }\end{array}$ \\
\hline $\begin{array}{l}\text { ha-šofțím ’af hisbíru ki “tamruréy ha-azhará } \\
\text { ha-'brurím še-maciv ha-ḥóq bi- dmut ha-man- } \\
\text { ganoním ha-šoním ha-klulím bo, mațratám } \\
\text { le-matén 'et ha-pgi á ba-zxut li-fratiyut ve- } \\
\text { ha-tqufá ha-mugbélet še-niqbé á milexathillá } \\
\text { be-yáḥas le-méšex toqpó šel ha-ḥóq.” }\end{array}$ & $\begin{array}{l}\text { The judges also explained that 'the clear warning } \\
\text { signs set by the law in the form of the various } \\
\text { mechanisms contained therein, are intended to } \\
\text { mitigate the violation of the right to privacy and } \\
\text { the limited period set from the outset in relation } \\
\text { to the duration of the law.' }\end{array}$ \\
\hline $\begin{array}{l}\text { hem hidgíšu ki '‘me-’áz hạaqiqát ḥóq hasmaxát } \\
\text { ha-šabák halu tmurót ve-šinuyím‘ uvdatiyím } \\
\text { mašma utiyím bi-tmunát ha-hitmodedut ‘im } \\
\text { ha-nagíf, u-vi-xlalám šiluš heqéf má aráx } \\
\text { ha-ḥaqirót ha-epidemiyologiyót ha-'enošiyót } \\
\text { ve-hitqadmutó šel mivcá' ha-ḥisuním }\end{array}$ & $\begin{array}{l}\text { They stressed that 'since the enactment of the GSS } \\
\text { Accreditation Law, there have been significant } \\
\text { and factual changes in the picture of dealing with } \\
\text { the virus, including the tripling of the scope of } \\
\text { the human epidemiological investigations system } \\
\text { and the progress of the vaccination campaign.' }\end{array}$ \\
\hline
\end{tabular}

In contrast with the analyzed Hebrew texts, described in the previous section (COVID-19 in legal documents in Hebrew), I did not find innovated lexical items in these MSA texts. All the words in this text already exist in MSA dictionaries, such as Qāmūs Al-Ma‘ānī [17] (online) and Wehr (1971) [31]. Yet for 'face mask' two words were used in Israel in the various texts: qinā' $^{6}$ and kimāma/kamāma. In fact, qinā' covers the whole face, while kimāma is the medical mask that covers the mouth and nose (also a muzzle for animals). It appears that the two options in the MSA in Israel were used in the early stages of the pandemic, until the kimāma prevailed. (In the Egyptian texts, only kimāma was used from the start.)

\subsection{Egyptian Arabic news/Media and the COVID-19 Pandemic News}

It appears that in Egypt, managing the pandemic was advancing more slowly (or more quietly) than in Israel. The Wikipedia sections about the pandemic in Israel and in Egypt announced in both of them that the first infected person was found in February. The number of sick people was smaller than in Israel at that time. The information about the pandemic might have been slow to reach the news, or slow to be published on the public media. However, on March 14 Egypt announced the locking down of all schools and higher education institutes to prevent spread of the virus in Egypt. On March 15th, 2020, when Israel was already locking down its business places and activities, a news report in Al-' Ahrām notified that the hospitals were raising their readiness degree to the top level, to face this virus. Then, on March 16th, the Egyptian airports were closed down. Financial and technical preparations were made to enable treating (paying) patients, and use new electronic tools for the checkups and treatment. In addition, the medical teams were promised to get the 


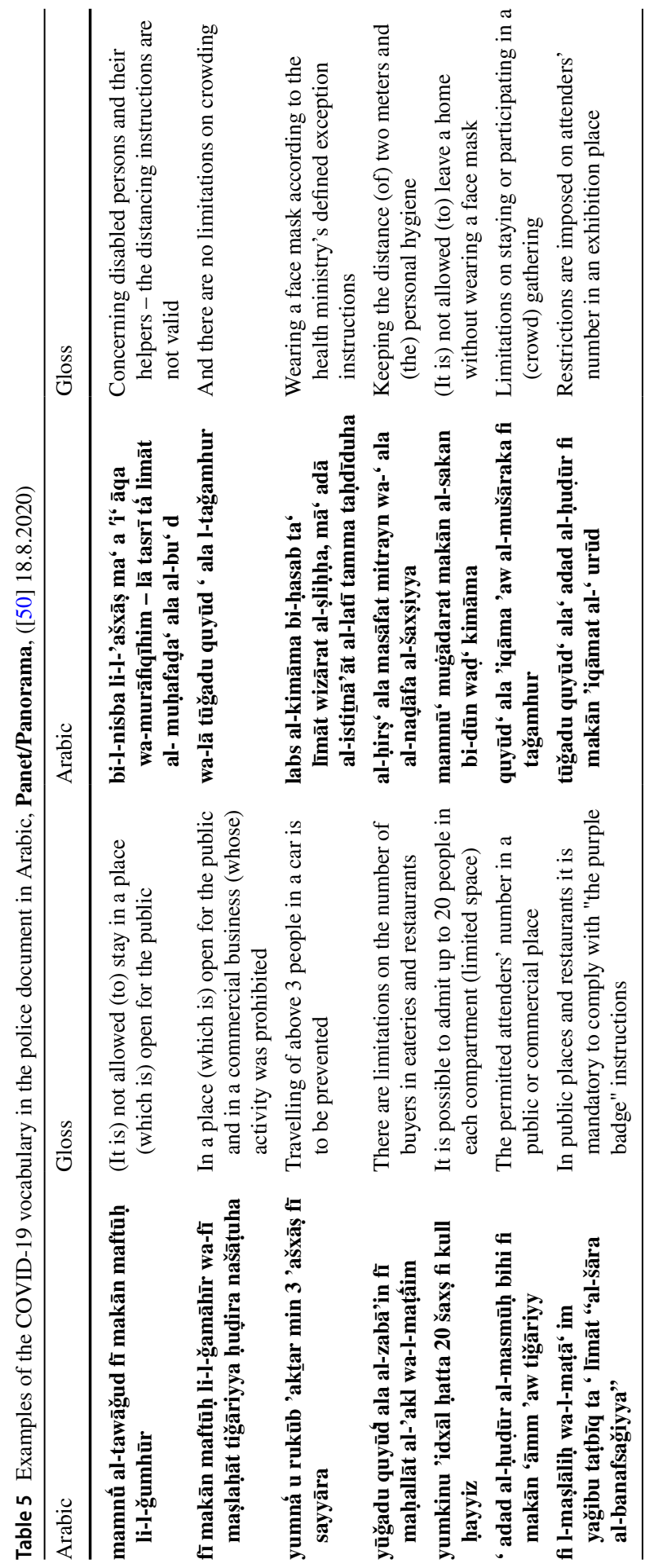


best devices to prevent them from being infected by the virus. Such terms and kind of discussions had been held in Israel already earlier. The pandemic was weakening during the summer of 2020 in Egypt. This could be due to the conditions in Egypt that differed from those in Israel. In any case, the Egyptian authorities and medical experts warned the population (e.g., [52] Al-' Ahrām, 30.9.2020) that this could be "the quiet before the storm." That is, if people did not obey the regulations, the pandemic would soon return with worse rates than previously, as witnessed in some European countries. Though the main news in Egypt reported at that time about politics, finance and society (e.g., less tourists in Sinai and Egypt, [52] Al-'Ahrām, 30.9.2020), the pandemic 'won' its specific sections in the media.

As noted, we used the Al-'Ahrām site and Al-Yawm Al-Sābi ${ }^{\bullet}$ site to study the pandemic vocabulary in Egypt. Some examples of the expressions used in a judicial report "the courts of justice" ([33] Bawwābat Al-'Ahrām) are presented below in Table 6. That report describes the renewed activity in the Egyptian courts, in particular those in Cairo (the capital of Egypt). ${ }^{4}$ That activity stopped for 2 months because of the pandemic, but was to resume in June 2020. The report explains (among other issues), that the court halls will be purged daily, all the judges, lawyers, and any other individual in the courts will have to wear face-masks and keep their fixed distance. The courts' security force will have special clothing to protect them from being infected by other people at the courts, etc.

This descriptive report shows a picture that is similar to the situation in Israel, and probably elsewhere. The situation in Egypt is more complicated and difficult to organize than in Israel, firstly due to the larger population and wider geographical area of Egypt. The Arabic MSA vocabulary about the pandemic is also very similar to that of Israel, as the issues and their management are similar in the present 'global village'. (cf. [29]. ${ }^{5}$

The topics of the Egyptian news reports and their style, as shown in Table 6, hardly differ from the Arabic texts of the newspapers/media in Israel. The expressions in Table 6 and the rest of the Egyptian material reflect four semantic areas (at least): judicial, medical, psychological, and administrative aspects, also found in the material from Israel. The examples from Egypt (Table 6) demonstrate, however, topics that differ from those presented in the above Tables from Israel. This variety shows the plethora of different issues in modern human life. When the collection of material ended, the pandemic was still at large in Egypt, and the Health Minister urged the population (April 22, 2021 [53]) to continue getting the necessary and free inoculation (at the expense of the government).

\section{Discussion and Conclusion}

The study started with the assumption that although Hebrew and Arabic in Israel and Egypt are sister languages in the Semitic language group, there might be differences between these languages in the realm of COVID-19-related/law-related semiotics (notwithstanding universal features of semiotic analyses). The paper showed

\footnotetext{
${ }^{4}$ Cairo and its suburbs has almost twice the number of population as in all of Israel.

${ }^{5}$ Other differences between MSA in Israel and Egypt are not discussed here.
} 


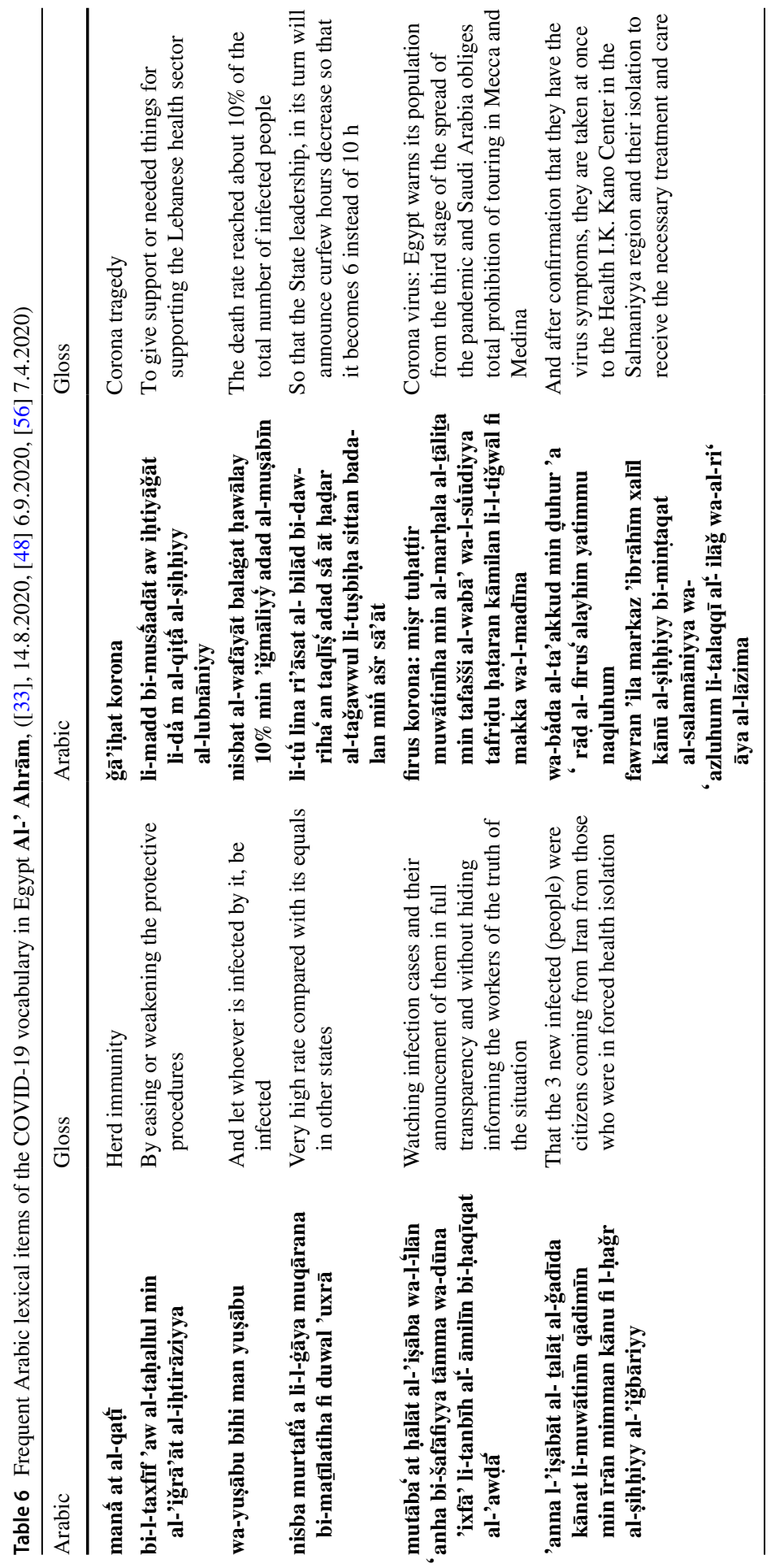


examples from the collected press material in these languages and compared their features by discussing expressions dealing with various aspects of the COVID-19 pandemic and its spread in these countries during 2020. The study had a legilinguistic-semiotic focus, which resulted in an interesting comparison.

The study has revealed several differences between each pair of comparisons (Hebrew vs. MSA-Israel; MSA-Israel vs. MSA-Egypt): MSA-Israel appears to be similar to Hebrew in various expressions, and MSA-Israel differs from MSAEgypt in others. The similarities between Hebrew vs. MSA-Israel seemed to be due to the fact that MSA in Israel was affected by Israeli Hebrew (by borrowing and code switching). The similarities between MSA-Israel and MSA-Egypt apparently reflected that both of them were MSA, and the world seemed to function in a similar way regarding the pandemic and the efforts to control and overcome it. These similarities were demonstrated in the vocabulary, which used many expressions translated from English into these language varieties. The law-related texts (and expressions) differed between Israeli Hebrew and Egyptian Arabic, however. This finding represented the different political, social and demographic structures of each country.

The various news reports in the Hebrew and Arabic materials referred to various law-related cases and events within the wide range of the COVID-19 effects and different manners and rates of presence. Therefore, a linguistically precise comparison of feature occurrences by statistical methods was impossible. However, the common topic, i.e., the pandemic, enabled defining major legilinguistic features in each of the three studied language groups.

Concerning the pandemic, the studied reports in Hebrew and Arabic showed similar semantic areas. The presented and discussed expressions reflected the stages witnessed in Israel, and some differences between them and those in Egypt. In addition, each Table in this paper presents examples of different topics, languages (Hebrew or Arabic) and sources (the news/media in these languages). These examples demonstrate the wide scope of the legilinguistic field, which covers all wakes of life all over the world, including the pandemic effects.

The study suggests that (at least) four semantic (and discursive) areas of frequent Modern Hebrew and MSA expressions are used in documents that involve legal issues during the COVID-19 period. These areas are:

1. Judicial aspects ('legalese', as evident in the vocabulary and grammar).

2. Psychological responses to the pandemic and its victims (in judicial texts, these occur less frequently than judicial aspects).

3. Medical/scientific aspects (referring to the treatment of various aspects of the pandemic and their expression in the legal field).

4. Administrative expressions.

The studied texts reflect both the authorities' requirements and the public's responses. The texts also reflect parts of the legal world, which deals with these areas, as with all the other issues that make modern life. 
Lack of innovated words in the Arabic texts contrasts the research hypothesis, but this fact is not surprising. For one, the Arabic texts in Israel reflect the effect of Hebrew on Arabic. Indeed, one of the texts discussed above is an accurate (and literal) translation of the Hebrew origin. It follows meticulously the Hebrew text. Other MSA-Israel texts on the internet news/media use freer style, sometimes using 'higher' (more formal) MSA. They use literal translations from Hebrew, and include more lexical varieties and syntactic patterns, as well as borrowed Hebrew words (e.g. kanyonāt 'shopping malls' < Hebrew qanyón 'a shopping mall') though not lexical innovations. It could be that Arabic lexical innovations concerning COVID19 should be sought in the colloquial register rather than in the formal MSA register, due to their different natures and communicational roles. (This assumption requires a separate study of colloquial dialects, which are beyond goals of the present study.) However, in all the three studied language varieties, the frequency of the pandemicrelated "medical parlance" has increased during this period, judging by the number of such reports in the studied sources.

In Israel, news reports during the COVID-19 period were divided mainly between the pandemic and internal political issues. Politics is always an important aspect of public life, and no wonder that it was found also in this pandemic period (cf. [1, 4, 29, 30]). In Israel, the political issues mainly focused on the PM's policy during the pandemic, on the one hand, and on his personal pending court cases and the accompanying public demonstrations, on the other. When the government finally fell, elections necessarily followed, exactly 3 months later, and the demonstrations ceased. (The new government was formed after the material collection for this study ended.)

In the studied Egyptian media, things looked different. I hardly found direct or indirect accusations or criticism of the Egyptian leadership's responsibility for the condition in the country. The reports did not blame the authorities for the problems that rose due to the pandemic (cf. [56, 57]). Reporters usually described the facts, or mentioned authorities' attention and manner of dealing with the crisis, also outside the Egyptian borders [54] and the problems that existed also in Egypt (and appeared marginally on the Egyptian news/media pages).

A few differences concerning the pandemic vocabulary in the two Arabic societies (in Israel and Egypt) were noted. An example noted above is the use of kimāma in Egypt and qină / kimāma in Israel for 'face-mask', which are nearly synonyms in MSA. Still, the masks that protect people against contracting COVID19 are not the masks of the past, which were used, e.g., for hiding one's identity. This is, then, a semantic meaning expansion in both these societies following the English communication means. Another example is the name for the virus. In Egyptian Arabic, it is fîrus korona al-mustağidd ('new (variety of) Corona virus'), whereas in Israel, the Arabic term is as in Hebrew fîrus al-korona or just korona.

The vocabulary is, of course, modern in the three studied language varieties, e.g. [10]. Like many other languages, Hebrew and Arabic have adopted many American English style and vocabulary elements, including the technical and medical expressions related to the current pandemic.

Official governmental announcements or parliament discussions (with e.g., judicial, and administrative expressions) are few in the news/media reports, due to 
their basic goal of addressing the general public rather than the professionals. The official regulation for behavior during the pandemic in Hebrew and Arabic were found in Israeli texts, including police announcements. In the Egyptian news/media, (official) announcements of the new regulations reflecting the authorities were found, but not the official documents (but see [45]). The pandemic issue stopped appearing on top of the first page of the news/media sometime in the middle of 2020 , but went on existing in internal pages of the news/media (see [44]). Summaries of new instructions and problematic events appeared on the news/media when they occurred. However, as noted, new expressions for the pandemic were hardly coined in the Egyptian news/media in Arabic.

A common feature of the COVID-19 vocabulary in Egypt and Israel seems to be that it has become a "normal" part of daily news and discourse, and therefore stopped appearing at the news/media headlines. This process may have followed news/media formats in the USA, etc. Along with this development, expressions that seemed new half a year previously, have become "common commodity" later on. Still, Hebrew and MSA technical and scientific expressions have become more frequent in daily news bulletins due to the pandemic; e.g., 'informatics' (Hebrew: meyda' anút, Arabic î lāmiyyāt); 'interjection', in an interview or public debate (Hebrew: qri'át beynáyim, or he‘ará 'a comment', Egyptian Arabic mudāxalah); or 'clinical experiments' (Hebrew nisuyím kliniyím, Egyptian Arabic tağārib sarīriyya, or tağārib iklinikiyya). Even the English 'hot line' for emergency information is simply a 'hot line' in both languages (Hebrew: ha-qáv ha-ḥám, Arabic: al-xațt al-sāxin).

The end of the pandemic was still unknown as of April 2021. Many people were getting used to 'live with the pandemic' by taking care and getting the vaccine. In Israel, the obligation of wearing facial masks outdoors and limiting daily activities was almost entirely dropped on 19.4.2021, but State economy, finance and unemployment rate were still threatening the return to normal life, very much as a result of decisions taken during the year and a half of the pandemic. In Israel, more than half the population was inoculated, and morbidity rate was nearly down to zero on 23.4.2021. Yet, the authorities kept warning people to go on taking care, in particular due to the newly spreading Delta variant of the COVID-19 virus. In contrast, in Egypt the news on the same day, 23.4.2021, warned that the rate of sick and dead people was on the increase. (By June 2021 the Delta virus was slowly spreading also in Israel.)

People's communication in this difficult time as reflected in the analyzed texts was full of expressions of worry, fear and aggressive force. The written words do not fully transmit these feelings, but semiotic analysis does suggest their existence and effects.

Many (non-judicial) questions are still unanswered: for how long will the inoculation be valid? Which inoculation will follow, if any? Which new mutations will be found? When will the pandemic disappear for good? No one can answer such questions at present. The judicial authorities, which are an inseparable part of the population, seem to struggle on, together with the rest of the people, as implied in their texts. The material analyzed here reflects the variegated semiotic nature of legilinguistic issues. 
The findings of these Hebrew and Arabic text features during the pandemic seem to point at features that differ from features discussed elsewhere in the Legilinguistics literature. More semiotic legilinguistic studies may contribute to the understanding of life in the shade of a modern pandemic.

\section{References}

1. Abbas, Ali Haif. 2020. Politicizing the Pandemic: A Schemata Analysis of COVID-19 News in Two Selected Newspapers. International Journal for the Semiotics of Law. https://doi.org/10.1007/ s11196-020-09745-2.Accessed15.4.2021.

2. Abu Bakr, Rafiq. 2005. Hebrew in Arabic Dressing (Ivrit Bi-levush 'Aravi) Baqa al-Gharbiyya: AlQasimi Academy (Hebrew).

3. Almog, Shulamit. 2006. Hebrew codification: Legal language and equality language, Mishpat va'Asaqim (Court (trial) and Business), 4: 1-23 (Hebrew).

4. Barzilai, Gad. 2007. The Ambivalent Language of Lawyers in Israel: Liberal Politics, Economic Liberalism, Silence and Dissent. In Fighting for Political Freedom: Comparative Studies of the Legal Complex and Political Liberalism, ch. 8, eds. Terry C. Halliday, Lucien Karpik, and Malcolm M. Feeley, 247-279.

5. Bousoffara-Omar, Naima. 2006. Diglossia. In Encyclopedia of Arabic Language and Linguistics, ed. Kees Versteegh, Vol. 1, 629-637. Leiden: Brill.

6. Brand, Sara. 2013a. Code switching among Arab students: Structural, socio-pragmatic and psycholinguistic dimensions, $\mathrm{PhD}$ dissertation, Ramat-Gan: Bar-Ilan University (Hebrew).

7. Brand, Sara. 2013b. The Arabs in Israel vs. Hebrew: Ways of adaptation - the influence of Hebrew on Arabic speech among its young speakers, meyda.education.gov.il, 89-101 (Hebrew) https:// meyda.education.gov.il/files/AdultEducation/gadish/sara_bernard.pdf. Accessed 12.March 2021.

8. Cohen, Smadar. 3.1.2021. From the diary of a language consultant: Word innovations in the Corona days. Talk in: Event for E. Avneyon's 90th birthday (Zoom session, Hebrew).

9. Eviatar, Zohar, and Rafiq Ibrahim. 2014. Why is it hard to read Arabic? In Handbook of Arabic Literacy: Insights and Perspectives, eds. Elinor Saiegh-Haddad and R. Malatesha Joshi, 77-96, Dordrecht: Springer.

10. El-Farahaty, Hanem. 2010. Lexical and syntax features of English and Arabic legal discourse: A comparative study. Comparative Legilinguistics 4:61. https://doi.org/10.14746/cl.2010.4.6

11. Ferguson, Charles Albert. 1959. Diglossia. Word 15: 325-340.

12. High Court of Justice. 25.11.2020 (updated). Court instructions. Instructions and behavior rules in courts and labor courts during the Corona period, updated, on: https://www.gov.il/he/departments/ general/the_judicial_authority_instructions_for_attendees. Accessed on 11.4.2021.

13. Edzard, Lutz. 1997. Language as medium of legal norm: the topics "war and peace" and "human rights" in bi- and multilingual treaties with Arab states and ogranizations. In Encounters of words and Texts: Intercultural Studies in Honor of Stefan Wild on the Occasion of his 60th Birthday, March 2, 1997 Presented by his Pupils in Bonn, ed. L. Edzard and Ch. Szyska, 69-110. Hildesheim: Georg Olms Verlag.

14. Kozanecka, Paulina, Matulewska, Aleksandra, and Trzaskawka, Paula. 2017. Methodology for Interlingual Comparison of Legal Terminology. Towards General Legilinguistic Translatology, Dissertationes Legilinguisticae 11 - Legilinguistic Studies 11, Studies in Legal Language and Communication, Poznan.

15. Al-Mar' i,'Abd al-Rahman. 2013. Walla Beseder: A Linguistic profile of the Israeli Arabs. Jerusalem: Keter (Hebrew).

16. Munahey Ha-Refu'ah (Medical Terminology). 1939. Leshonenu, vol. 7: 89-91, 263-266 (English/ Hebrew) https://terms.hebrew-academy.org.il/Millonim/Details/82. Accessed 1.4.2021.

17. Qāmūs Al-Ma ānī. https://www.almaany.com/ar/dict/ar-en/. (Arabic) Accessed on 1.1.2020.

18. Rosenhouse, Judith, and Sara Brand. 2016. Arabic-Hebrew Code-Switching in the Spontaneous Speech of Israeli Arab Students. In Arabic Varieties: Far and Wide: Proceedings of the 11th International Conference of AIDA - Bucharest, 2015, eds. George Grigore and Gabriel Biţună ,467-474 
19. Rouchdy, Aleya (ed.). 2002. Language Contact and Language Conflict in Arabic. Surrey: RoutledgeCurzon.

20. Saiegh Haddad, Elinor, and Rony Henkin. 2014. The structure of Arabic language and orthography. In Handbook of Arabic Literacy: Insights and Perspectives, eds. Elinor Saiegh-Haddad and R. Malatesha Joshi. 3-28. Dordrecht: Springer.

21. Sappan, Rafael. 1963. Slang Ways: Meaning and Form Phenomena in Sub-standard Hebrew. Jerusalem: Kiryat Sefer Ltd. (Hebrew).

22. Shemy, Amany. 2020. Fachsprachenphraseologismen - eine kontrastive rechts-linguistische Untersuchung am Beispiel des deutschen und arabischen Strafurteils. Comparative Legilinguistics 42: 93-125.

23. Shetah, Yoseph. 2013. Interview with Judge Y. Shneller Lashon U-Mishpat (Language and Law) 2: 1-5 (Hebrew) https://din-online.info/pdf/alon1.pdf. (Accessed last on 13.4.2021)

24. Shetah, Yoseph (n.d.) Language and court cases. Bulletin for judicial language, The Israel Bar, TelAviv District. https://ibar.org.il/images/hamitmache/alon.pdf (Hebrew). Accessed last on 13.4.2021.

25. Shklar-Hemo, Avia. 16.8.2018. Meet 'Aravrit - the new language of the Arabs of Israel. Maqor Rishon https://www.makorrishon.co.il/magazine/dyukan/63267/. (in Hebrew).

26. Spolsky, Bernard Dov, and Elana Shohamy Goldberg. 1999. The Languages of Israel: Policy, Ideology and Practice. Clevedon, England: Multilingual Matters.

27. Shehadeh, Haseeb. 1997. The Hebrew of the Arabs in Israel (in the light of two matriculation examinations, 1970, 1972). In Nordic Research on the Middle East 3, Ethnic Encounter and Culture Change, Papers form the Third Nordic Conference on Middle Eastern Studies, Joensuu, 1995, eds. M'hammed Sabour and Knut S. Vikør 49-71.

28. Shehadeh, Haseeb. 2019. On the Arabic in Israel. Annals of Language and Literature 3 (1): 27-42.

29. Wagner, Anne, Aleksandra Matulewska, and Sara Marusek. 2021. Pandemica Panoptica: Biopolitical Management of Viral Spread in the Age of Covid-19. International Journal for the Semiotics of Law. https://doi.org/10.1007/s11196-021-09821-1.

30. Wang, Mingyu. 2020. Linguistic Semiotics. Peking: Springer.

31. Wehr, Hans. 1971. A Dictionary of Modern Written Arabic. Wiesbaden: Verlag Otto Harrassowitz (Arabic-English).

32. Zidan, Ahmed Abdelmoneim, and Youssef Masry. 2015. A Linguistic Analysis of Some Problems of Arabic-English Translation of Legal Texts, with Special Reference to Contracts. Poznań: Cambridge Scholars Publishing Communication, Wydawnictwo Naukowe.

\section{Websites}

33. Al-'Ahrām/Bawwābat al-'Ahrām (The Pyramides/the Pyramides Gate) https://www.ahram.org. eg/. (Arabic).

34. Al-Yawm Al-Sābi '/Axbār Al-Yawm Al-Sābi (The seventh day/News of the seventh day) (Arabic).

35. Central Bureau of Statistics. Press release. Israeli population at the beginning of 2020. Jerusalem, Israel. https://www.cbs.gov.il/he/mediarelease/pages/2019/\%D7\%90\%D7\%95\%D7\%9B\%D7\%9C\% D7\%95\%D7\%A1\%D7\%99\%D7\%99\%D7\%AA-\%D7\%99\%D7\%A9\%D7\%A8\%D7\%90\%D7\%9C-\% D7\%91\%D7\%A4\%D7\%AA\%D7\%97\%D7\%94-\%D7\%A9\%D7\%9C-\%D7\%A9\%D7\%A0\%D7\%AA2020.aspx.

36. Hebrew and the corona virus (in Hebrew) https://hebrew-academy.org.i1/2020/03/08/\%D7\%94\% D7\%A2\%D7\%91\%D7\%A8\%D7\%99\%D7\%AA-\%D7\%95\%D7\%94\%D7\%A0\%D7\%92\%D7\%99\% D7\%A3-\%D7\%A7\%D7\%95\%D7\%A8\%D7\%95\%D7\%A0\%D7\%94/.

37. Kull Al-'Arab (All the Arabs) https://www.alarab.com/1.html (Arabic).

38. Kull Al-'Arab https://he.wikipedia.org/wiki/\%D7\%90\%D7\%9C\%D7\%99\%D7\%95\%D7\%9D_\%D7\% 90-\%D7\%A1\%D7\%90\%D7\%91\%D7\%A2 (Arabic). Accessed 5.2.2020.

39. Panet/Panorama https://www.panet.co.il/category/106 (Arabic).

40. Panorama https://he.wikipedia.org/wiki/\%D7\%A4\%D7\%A0\%D7\%95\%D7\%A8\%D7\%9E\%D7\% 94_(\%D7\%A2\%D7\%99\%D7\%AA\%D7\%95\%D7\%9F) (Arabic)

41. Yisra'el Ha-Yom (Israel Today) https://www.israelhayom.co.il/news (Hebrew)

42. Ynet/Yedi'ot 'Aḥaronot (Recent News) https://www.ynet.co.il/news (Hebrew) 


\section{Reports on the web}

43. Altman, Yair, 1.3.2021. The vice health Minister Kish: "The High court of Justice decision to decrease positioning - is a crime against Israeli citizens" Yisra'el Ha-Yom, https://www.israe lhayom.co.il/article/856517 (Hebrew). Accessed 1.3.2021.

44. Fikri, Ayman. 30.9.2020 Quiet before the storm... hiding of the corona "fobia" warns against the approaching 2nd wave/// and doctors explain the reasons for the decreasing number of cases Bawwābat Al-'Ahrām. https://gate.ahram.org.eg/News/2497554.aspx (Arabic). Accessed 1.10.2020.

45. Fu'ad, Fatma. 23.5.2020. The courts of justice. Bawwābat Al-'Ahrām. https://gate.ahram.org.eg/ News/2410211.aspx (Arabic). Accessed 24.5.2020.

46. Kahana, Ariel, 17.9.2020. Yisrabluff under the auspices of the government: Thus fell the lockdown outline and forced the emerging aggravation of the limitations Yisrael Ha-Yom. https://www.israe lhayom.co.il/article/802267 (Hebrew). Accessed 25.9.2020.

47. Kahana, Ariel, Shlesinger, Yehuda, Altman Ya'ir and editors of Yisra'el Ha-Yom, 22.9.2020. The Corona cabinet has dispersed without decisions; Netanyahu, "we will make important decisions already tomorrow". Yisra'el Ha-Yom. (Hebrew). https://www.israelhayom.co.il/article/803311. Accessed 25.9.2020.

48. Nașr, Samar. 14.8.2020. Egypt's ambassador in Lebanon hands over 2 tons of medical supplies to the governmental quarantine hospital in Beirut. (Arabic). Bawwābat Al-Ahrām. https://gate.ahram. org.eg/News/2449779.aspx. Accessed 15.8.2021.

49. Police document. 17.8.2020 (Hebrew) Accessed 20.8.2020. http://govilmvcdemo.westeurope.cloud app.azure.com/he/departments/news/police_covid-19_information_general

50. Police document. 18.8.2020 (Arabic) Accessed 20.8.2020. http://govilmvcdemo.westeurope.cloud app.azure.com/ar/departments/news/police_covid-19_information_general

51. Rosenthal, Rubi. 23.4.2020. Ha-Zira Ha-Leshonit (The Language Circus), https://www.israelhayom. co.il/tags/\%D7\%94\%D7\%96\%D7\%99\%D7\%A8\%D7\%94-\%D7\%94\%D7\%9C\%D7\%A9\%D7\%95\% D7\%A0\%D7\%99\%D7\%AA?page=1. Accessed 10.9.2020. (Hebrew). Accessed 25.4.2020.

52. Al-Ṣubayhi, 'Abd-Allah. 30.9.2020. Health: New 124 positive Corona virus cases registered and 13 deaths, Al-’Ahrām Gate. https://gate.ahram.org.eg/News/2497171.aspx (Arabic). Accessed 1.10.2020.

53. Al-Subayhi, 'Abd-Allah. 22.4.2021. Health: Sending messages to the citizens about continuation of the decisions of treatment on account of the State. Bawwābat Al-'Ahrām https://gate.ahram.org.eg/ News/2699171.aspx (Arabic). Accessed 15.9.2020.

54. Al-Subayhi, ‘Abd-Allah. 6.9.2020. The Health Minister stresses Egypt's full readiness to support the health sector in Lebanon Bawwābat Al-Ahram. Arabic Accessed 15.9.2020. https://gate.ahram. org.eg/News/2458267.aspx

55. Yas ${ }^{`}$ ur-Beit-Or, Meytal. 23.9.2020. Interim results encourage the experimental treatment by antibodies, Yisra'el Ha-Yom, https://www.israelhayom.co.il/article/803369 (Hebrew). Accessed 24.9.2020.

56. Bawwābat Al-'Ahrām. 7.4.2020. Opinions: Herd immunity will win! (Arabic) https://gate.ahram. org.eg/News/2393032.aspx. Accessed 15.9.2020.

57. Sayf-Al-Dawla Hamdan, Ilham. 24.3.2020. Opinions: Demonstrations... against an unknown! Bawwābat Al-Ahram https://gate.ahram.org.eg/News/2387896.aspx (Arabic). Accessed 25.4.2020.

Publisher's Note Springer Nature remains neutral with regard to jurisdictional claims in published maps and institutional affiliations.

Springer Nature or its licensor (e.g. a society or other partner) holds exclusive rights to this article under a publishing agreement with the author(s) or other rightsholder(s); author self-archiving of the accepted manuscript version of this article is solely governed by the terms of such publishing agreement and applicable law. 